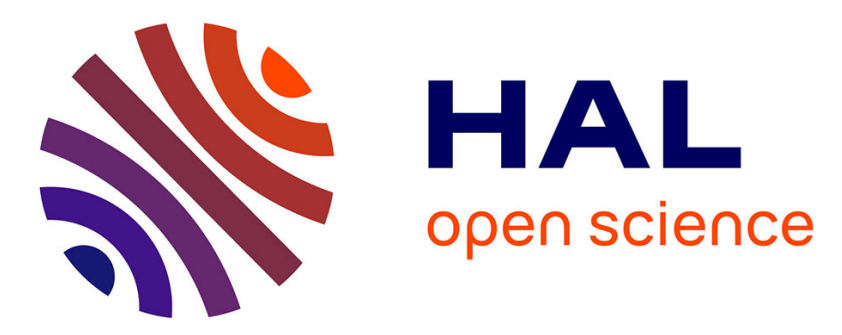

\title{
Egg production in a whitefish ( Coregonus shinzi palea) brood stock: effects of photoperiod on the timing of spawning and the quality of eggs \\ C. Gillet
}

\section{- To cite this version:}

C. Gillet. Egg production in a whitefish ( Coregonus shinzi palea) brood stock: effects of photoperiod on the timing of spawning and the quality of eggs. Aquatic Living Resources, 1991, 4 (1), pp.33-39. hal-02712244

\section{HAL Id: hal-02712244 \\ https://hal.inrae.fr/hal-02712244}

Submitted on 1 Jun 2020

HAL is a multi-disciplinary open access archive for the deposit and dissemination of scientific research documents, whether they are published or not. The documents may come from teaching and research institutions in France or abroad, or from public or private research centers.
L'archive ouverte pluridisciplinaire HAL, est destinée au dépôt et à la diffusion de documents scientifiques de niveau recherche, publiés ou non, émanant des établissements d'enseignement et de recherche français ou étrangers, des laboratoires publics ou privés. 


\title{
Egg production in a whitefish (Coregonus shinzi palea) brood stock: Effects of photoperiod on the timing of spawning and the quality of eggs
}

\author{
Christian Gillet \\ LWRA, Station d'Hydrobiologie Lacustre, BP SII, 74203 7honon-les-Bains C'edex, France.
}

Received June 6, 1990; accepted November 26 , г99\%.

\begin{abstract}
The results of preliminary experiments in the development of a hatchery brood stock of whitefish of Lakc Geneva, Coregonus shinzi palea Cuv. and Val. (lavaretus), are described. Factors likely to influcnce the date of spawning and the quality of eggs were studied by reference to the performance of wild spawners from the Lake Gencva. Fish were reared in tanks and the ovulation of females occurred spontancously at the same spawning time as in wild spawners from the lake. Reared females have produced $30000 \mathrm{eggs} / \mathrm{kg}$ against 45000 in wild fish. The survival rate of a domestic egg was about $10 \%$ less than that of wild females. Since the overripening of the ova was rapid it was necessary to check the ripe females twice a week. The exposure of fish to long days in autumn delayed spawning by two months and permitted the synchronization of hatching under optimal conditions of growth. The ovulations were spread over a period of 3 months when the fish were subjected to long days until spawning. In contrast, termination of the long day regime in December induced a synchronization of the ovulations over just one month.
\end{abstract}

Gillet C. Aquat. Living Resour., 1991, 4, 33-39.

Keywords : Coregonid fish, whitefish, reproduction, fecundity, cggs, overripening, photoperiod.

Production d'aufs par des géniteurs de corégone en élevage: effets de la photopériode sur la date de fraie et sur la qualité des oufs.

Résumé

Cet article décrit les premiers résultats d'une tentative de développement d'un stock de géniteurs de corégone (Féra du Léman) en élevage. Le rôle des facteurs susceptibles d'avoir une influence sur la date de reproduction et qualité des aufs est évalué en prenant pour référence les performances des géniteurs sauvages du lac Léman. Les poissons sont élevés en bassin et l'ovulation des femelles se produit spontanément aux dates habituelles de fraie des corégones sauvages du lac Léman. Les femelles d'élevage produisent 30000 oufs $/ \mathrm{kg}$ contre 45000 pour les poissons sauvages. Le pourcentage de survie des oufs d’élevage est légèrement inférieur $(10 \%)$ à celui des oufs des poissons sauvages. Le processus de surmaturation des ovules est très rapidc, en conséquence il s'avère nécessaire de contrôler les femelles deux fois par semaine pendant la phase des ovulations. Le conditionnement des poissons en jours longs en automne permet de retarder de deux mois la période de reproduction. Cette technique devrait permettre de produire des larves tardives, dont l'éclosion serait synchronisće avec des conditions optimales de température pour leur première croissance. La période des ovulations s'ćtale sur 3 mois lorsque les poissons sont conditionnés en jours longs jusqu'à la fraie tandis que l'arrêt du traitement en jours longs en décembre permet de synchroniser les ovulations sur un mois.

Mots-clés : Coregonus, reproduction, fécondité, qualité des æufs, ovules, photopériode, surmaturation. 


\section{INTRODUCTION}

Whitefish are found in the French Alpinc lakes and they are important species for fishermen. During recent years, catches have dramatically declined in many lakes in relation to eutrophication and there is some evidence that coregonid populations can be restored by stocking (Wilkonska and Zuromska, 1982; Luczynski, 1986). The purpose of the present experiment was to test the quality of egg production in a coregonid brood stock, fed with a dry food and reared in tanks. This may lead to egg production in reared corcgonid fish and would allow intensification of stocking and development of aquaculture of these species.

Mass rearing of coregonid larvae in tanks with dry food has been achieved recently (Champigneulle, 1988; Rösch, 1988). As the continuation of this research, whitcfish from Lake Geneva (Coregonus shinzi palea Cuv. and Val.) were reared to the spawner stage in tanks from fingerlings fed with dry food. Brood stock obtained has been examined with respect to influence of the spawning time and the quality of eggs. Intensively reared spawners were compared to wild coregonids from Lake Geneva. Delayed spawning by the use of artifical photoperiod regimes was also investigated. Such an approach would allow the delay of hatching without using refrigerated water.

\section{MATERIAL AND METHODS}

\section{Origin of fish}

The whitefish brood stock was obtained from eggs of wild fish caught in Lake Geneva in 1983 and 1984. Three-year-old, 600-800 g fish were used. Fertilization, incubation and feeding of the larvae were described in Champigneulle and Rojas (1990).

\section{Rearing procedures}

Whitefish spawners were kept in 4 and 12 cubic metre tanks, supplied with water pumped from Lake Geneva. Water temperature fluctuated between 5.5 and $11^{\circ} \mathrm{C}$ when supplied from a depth of $36 \mathrm{~m}$ and between 5.5 and $22^{\circ} \mathrm{C}$ when supplied from $4 \mathrm{~m}$ depth in Lake Geneva. In summer, the temperature in the rearing tanks was maintained at $16^{\circ} \mathrm{C}$ by mixing water from the two depths. Fish were fed with dry pellets (trout commercial food, Trouvit, protein $42 \%$, lipid $12 \%$ ) distributed 8 hours daily with automatic feeders. Food was offered at a ratio between 0.5 and $2 \%$ of body weight, according to water temperature $(0.5 \%$ at $5.5^{\circ} \mathrm{C}$ and $2 \%$ at $16^{\circ} \mathrm{C}$ ). Females became mature in their second or third year, for both cultivated and wild fish of Lake Geneva. In the present experiment first spawning and two-year-old females were excluded owing to the poor quality of sexual products of first spawning females in coregonid fish (Kalmer et al., 1982). The age of mature females was indicated for each experiment in tables and figures.

\section{Experiments on photoperiod}

Coregonid spawners were reared under 17 hours of light per day (17L-7 D). Fish were conditioned in long days from 15 July 1986 to 19 February 1987 , from 15 August 1987 to 15 December 1987 and from 21 June 1988 to 1st December 1988. In 1988 another experimental group was kept in long days from 15 September to 1 st December. Light regimes were provided by $60 \mathrm{~W}, 24 \mathrm{~V}$ bulbs and controlled by a time switch. Light intensity at water surface was about 150) lux (measured by a luxmetre compact ChauvinArnoux).

\section{Detection of ovulation, fertilization and incubation}

Once first ovulations were recorded, females were regulary examined. Mean frequency of examination in cach experimental group is detailed in table 2. Each ovulated female was anaesthetized in 2 phenoxyethanol $(0.3 \mathrm{mg} / \mathrm{l})$, and weighed to the nearest $0.1 \mathrm{~g}$. Ova were collected, drained and weighed to the nearest $0.1 \mathrm{~g}$. About fifty ova were weighed to the nearest $0.1 \mathrm{mg}$ in order to determine the mean weight per ovum and the relative Secundity of the female (number of ova/g of body weight). Ova were fertilized in a diluter for artifical fertilization (Billard, 1977), adapted to whitefish (Gillet and Roubaud, 1986) with a pool of spermatozoa from several males. Milt was diluted at a ratio of $10^{-2}$. Twenty minutes later, eggs were washed and then incubated at $5^{\circ} \mathrm{C}$. Groups of two hundred eggs were shifted into a $10 \mathrm{~cm}$ Petri dish with $5 \mathrm{~mm}$ of water. Water was renewed three times a week. When embryos had reached 120 degrec-days (stage tail bud) survival rate was determined using a binocular microscope. Wild femalcs were caught with gillnets on the spawning grounds of Lake Geneva in December. Their ova were inseminated and incubated following the same procedure as for the reared spawners.

\section{Study on the ageing of ova}

The decrease in ova fertility after ovulation was estimated by inseminating small quantities of ova from the day were ovulations were recorded (day 0 ) and at 2 or 3 day-intervals thereafter until day 8 . Each time, about 200 ova were stripped from each female and immediately fertilized. This study was carried out on domestic females, kept in tanks at $5^{\circ} \mathrm{C}$, 7 and $11^{\circ} \mathrm{C}$ after ovulation. The same study was done for wild ripe females, caught from Lake Geneva and then kept at $5^{\circ} \mathrm{C}$ in tank. Nets were set for two hours at dusk, in shallow water (mean depth of five metres). 


\section{Statistical analysis}

Means for the different experimental groups (relative fecundity, ova weight and egg survival rates) were compared by using a Student's test. The use of relative fecundity assumes that there is no correlation between body weight and relative fecundity. The correlation between $\log$ (relative fecundity) and $\log$ (body weight) was calculated for both wild and reared females.

\section{RESULTS}

\section{Growth (fig. 1, tabl. I)}

Reared whitefish grew more slowly than wild spawners in Lake Geneva. Histograms of frequency
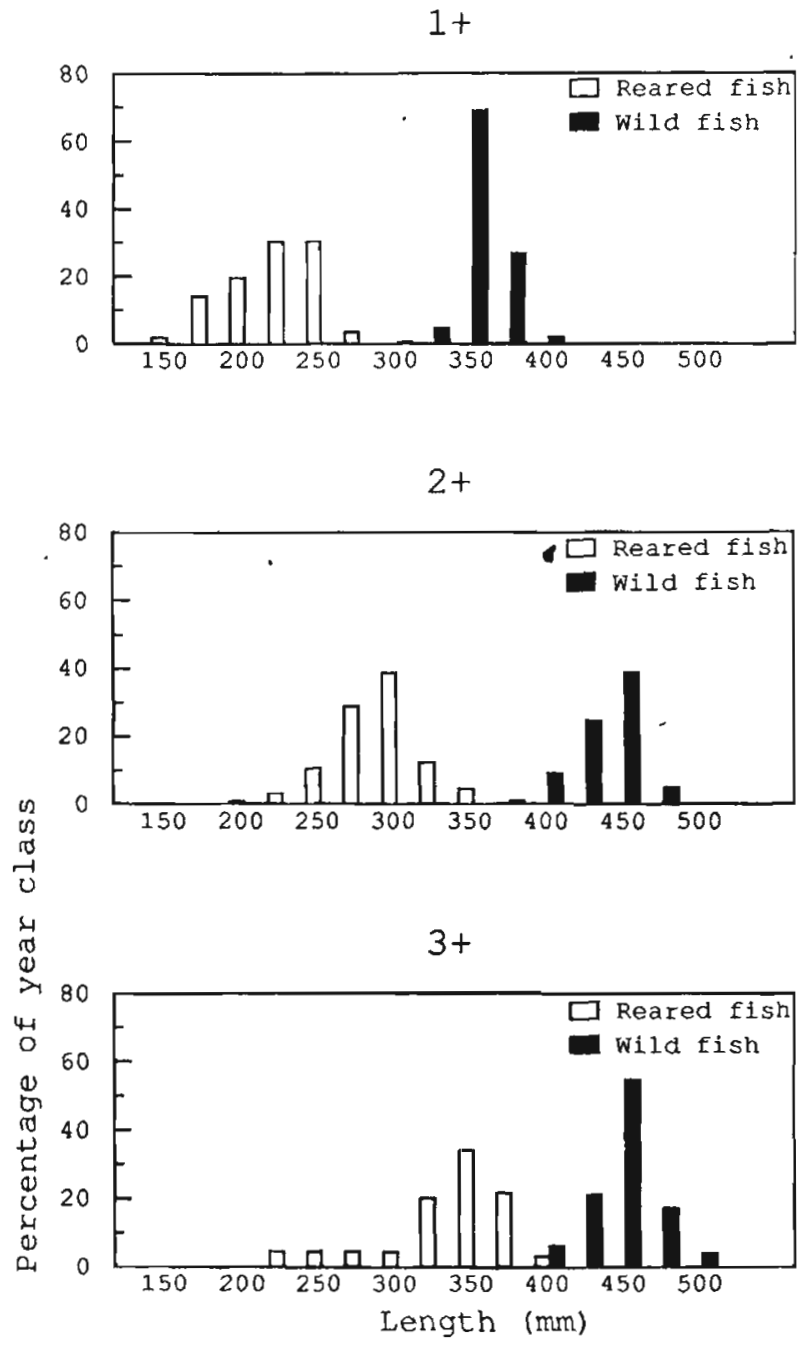

Figure 1. - Frequency distribution of total lengths for whitefish of both sexes of ages $1+(2$ years $), 2+$ and $3+$. Comparison between wild fish of Lake Geneva (from Gerdeaux, 1985) and reared fish. Wild fish were aged by examination of scales. distribution of total length for three age groups, $1^{+}$ $2^{+} 3^{+}$, did not overlap for wild and reared fish.

Table 1. - Mean length of coregonid fishes reared in tank with dry pellets. Number of fish in brackets.

\begin{tabular}{cr}
\hline Age (years) & \multicolumn{1}{c}{ Length (mm) } \\
\hline 2 & $(57) 229.26 \pm 5.04$ \\
3 & $(376) 299.04 \pm 1.65$ \\
4 & $(67) 350.10 \pm 5.32$ \\
5 & $(24) 414.58 \pm 5.09$ \\
\hline
\end{tabular}

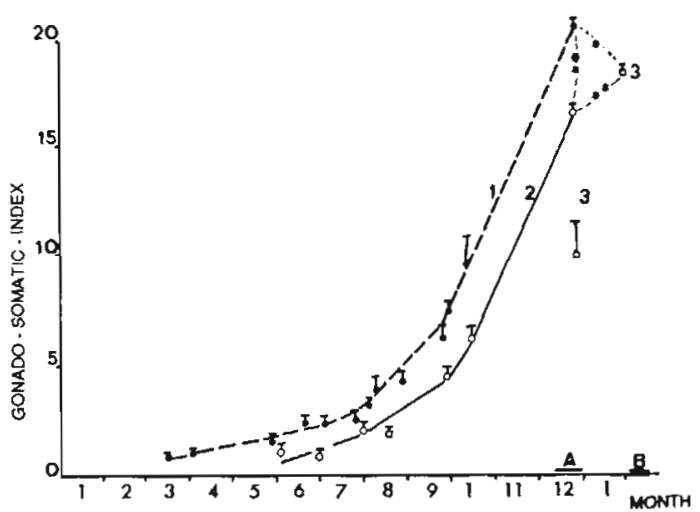

Figure 2. - Monthly development of gonado-somatic indcx (GSI) of females whitefish. 1: wild fish in Lake Genevà. 2: reared fish in natural photoperiod. 3: reared fish under long days (17 L-7 D) from 15 August 1987 to 15 December 1987. A: Spawning period for fish under natural photoperiod. B: Spawning period for fish in long days. Significant differences are indicated by $*$ for $P<0.05$ and by ** for $P<0.01$. Wild females were 3 and 4 years old. Reared females were 3 years old (group 2) and 4 years old (group 3 ).

\section{Females' gonado-somatic index (GSI) (fig. 2)}

Ovaries of wild females slowly developed from May to September, then quickly grew in October, November and December. Ovaries of reared females kept under natural photoperiod had an identical developmental rhythm to the one of wild females though their GSI was always lower. The ovaries of fish kept under long days from 15 August 1987 to 15 December 1987 have a slower developmental rhythm than the fish kept under natural photoperiod. From midDecember, the long day regime was stopped and the ovaries grew quickly. At the end of January, GSI of these fish was higher than the maximum value reached by reared fish kept under natural photoperiod.

\section{Timing of ovulation (fig. 3)}

Females kept under natural photoperiod started to ovulate at the end of November (1986 and 1988) or at the beginning of December (1987). Ovulations for the whole population lasted between 15 days (1988) and 1.5 months (1987). Fish kept under long days started to ovulate at the end of January (1987 

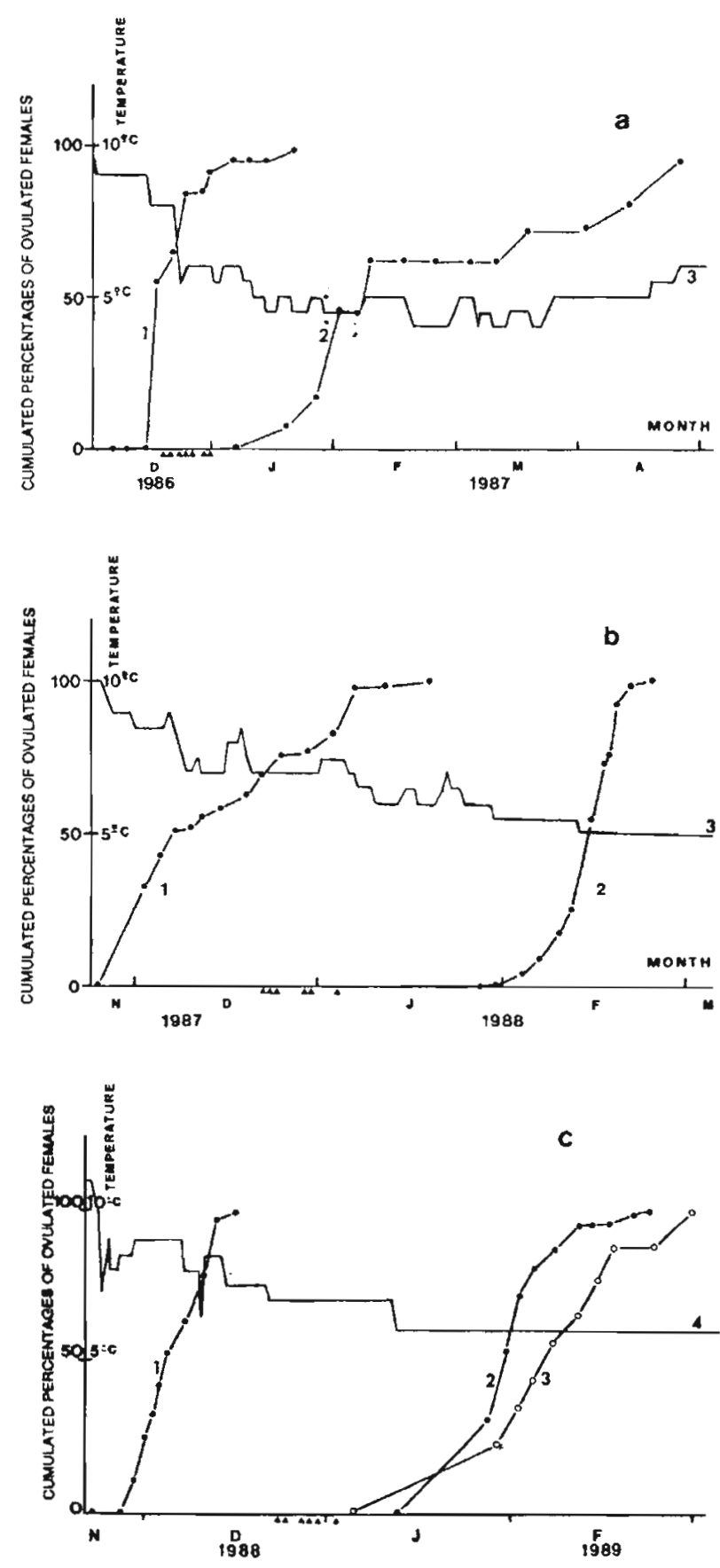

Figure 3. - Profiles of cumulated percentages of ovulatcd females: a: In winter 1986-1987. 1: Fish reared in natural photoperiod. 2 : Fish reared under long days (17 L-7D) from 15 July 1986 to 19 February 1987. 3: Temperature of rearing tanks. b: In winter $1987-$ 1988. 1: Fish reared under natural photoperiod. 2: Fish reared under long days ( $17 \mathrm{~L}-7 \mathrm{D}$ ) from 15 August 1887 to 15 December 1987. 3: Temprature of rearing tanks. c: In winter 1988:1989. I: Fish reared under natural photoperiod. 2: Fish reared under long days from 21 June 1988 to 1 December 1988. 3: Fish reared under long days from 15 September 1988 to 1 December 1988. 4: Temperature of rearing tanks. Arrows indicate the dates of fishing of ripe females on the spawning grounds in Lake Geneva. Ages of females are given in table 2.
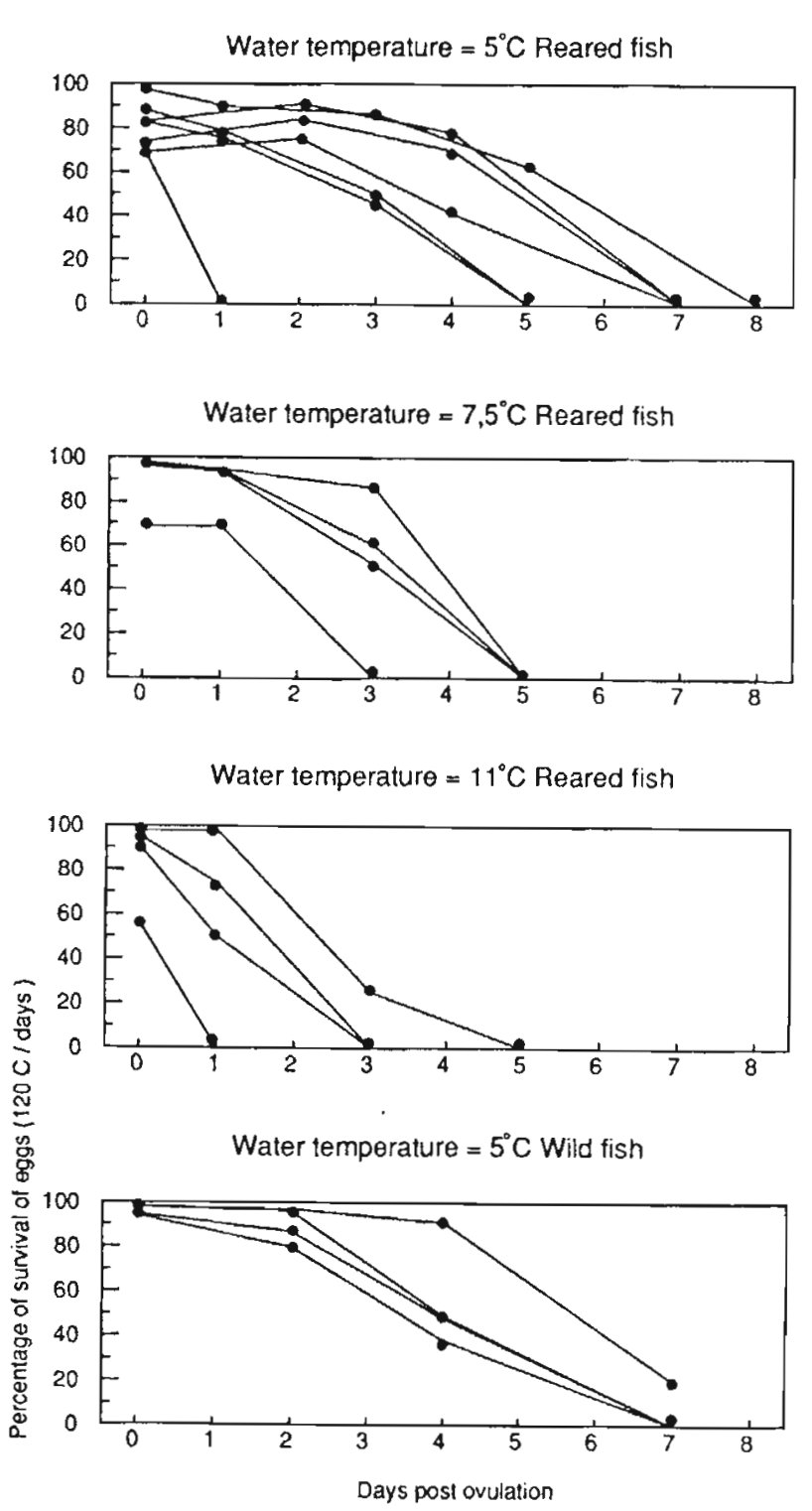

Figure 4. - Effect of overripening of ova on percentages of survival of eggs at 120 degree-days. Reared females are kept in tanks at three different temperatures $5-7.5-11^{\circ} \mathrm{C}$ after the ovulation. Wild ripe females arc kept at $5^{\circ} \mathrm{C}$.

and 1989) or at the beginning of February (1988). Ovulations lasted 15 days in 1988 and one month in 1989. In these two cases, conditioning of fish under long days was stopped in December. In 1987 a long day regime was applied until 10 February 1987 and ovulations lasted more than three months.

\section{Survival rates of embryos at 120 degree-days ( $t a b l .2)$}

Survival of eggs from wild females $(86 \%)$ was higher than that of all the different groups of reared females. The percentage of fertilized eggs of reared 
Table 2. - Survival of coregonid eggs at 120 degree-days for wild and reared females. Number of fish in brackets. Significant differences are indicated by * for $\mathrm{P}<0.05$ and ** for $\mathrm{P}<0.01$.

\begin{tabular}{|c|c|c|c|c|}
\hline Origin of females & $\begin{array}{c}\text { Age } \\
\text { (years) }\end{array}$ & $\begin{array}{l}\% \text { of survival } \\
\text { of embryos } \\
\text { at } 120^{\circ} \mathrm{C} / \mathrm{D}\end{array}$ & $\begin{array}{l}\text { Statistical analysis } \\
\text { between wild and } \\
\text { reared fernales }\end{array}$ & $\begin{array}{c}\text { Mean number } \\
\text { of days between } \\
\text { two examinations } \\
\text { of females }\end{array}$ \\
\hline Wild females & $3-4$ & (48) $86.36 \pm 2.14$ & & \\
\hline \multicolumn{5}{|l|}{ Reared females: } \\
\hline \multicolumn{5}{|l|}{ A) Natural photoperiod } \\
\hline 1 winter $1986 / 1987$ & 3 & (54) $73.88 \pm 3.60$ & ** & 3.8 \\
\hline 2 winter $1987 / 1988$ & 3 & (113) $64.39 \pm 2.75$ & ** & 5.6 \\
\hline 3 winter $1988 / 1989$ & 4 & (37) $75.06 \pm 4.35$ & * & 2.9 \\
\hline \multicolumn{5}{|l|}{ B) Long days (17L-7D) } \\
\hline 1 winter $1987 / 1988$ & 4 & (55) $76.59 \pm 3.50$ & $*$ & 2.2 \\
\hline 2 winter $1988 / 1989$ & 4 & (53) $76.88 \pm 3.06$ & * & 3.2 \\
\hline
\end{tabular}

Table 3. - Mean weight of ova for wild and reared coregonid females. Number of fish in brackets. Significant differences are indicated by * for $\mathrm{P}<0.05$, by ** for $\mathrm{P}<0.01$ and by NS for $\mathrm{P}>0.05$.

\begin{tabular}{|c|c|c|c|c|c|}
\hline \multirow{2}{*}{$\begin{array}{c}\text { Number } \\
\text { of each } \\
\text { experimental } \\
\text { group }\end{array}$} & \multirow[b]{2}{*}{ Origin of females } & \multirow[b]{2}{*}{$\begin{array}{c}\text { Age } \\
\text { (years) }\end{array}$} & \multirow[b]{2}{*}{$\begin{array}{l}\text { Weight of one ovum } \\
\text { (mg) }\end{array}$} & \multicolumn{2}{|c|}{ Statistical analysis } \\
\hline & & & & $\begin{array}{l}\text { a) between wild } \\
\text { and reared females }\end{array}$ & $\begin{array}{l}\text { b) between natural } \\
\text { and long day }\end{array}$ \\
\hline$!$ & $\begin{array}{l}\text { Wild females } \\
\text { Reared females: }\end{array}$ & $3-4$ & (28) $5.56 \pm 0.14$ & & \\
\hline & $\begin{array}{l}\text { A) Natural photo- } \\
\text { period: }\end{array}$ & & & & \\
\hline 2 & winter $1986 / 1987$ & 3 & (86) $5.33 \pm 0.06$ & $1-2=\mathrm{NS}$ & $2.5=* *$ \\
\hline 3 & winter $1987 / 1988$ & 3 & (82) $4.98 \pm 0.08$ & $1-3=* *$ & $3-6=*$ \\
\hline 4 & winter $1988 / 1989$ & 4 & (40) $5.69 \pm 0.14$ & $1-4=\mathrm{NS}$ & $4-7=* *$ \\
\hline & $\begin{array}{l}\text { B) Long days (17 L- } \\
7 \mathrm{D}) \text { : }\end{array}$ & & & & \\
\hline 5 & winter 1987 & 3 & (10) $4.33 \pm 0.24$ & $1-5=* *$ & \\
\hline 6 & winter 1988 & 4 & (54) $4.73 \pm 0.09$ & $1-6=* *$ & \\
\hline 7 & winter 1989 & 4 & (53) $4.95 \pm 0.10$ & $1-7=* *$ & \\
\hline
\end{tabular}

Table 4. - Relative fecundity of wild and reared coregonid females. Number of fish in brackets. Significant differences are indicated by * for $P<0.05$ and by ** for $P<0.01$ and NS for $P>0.05$. Relative fecundity is expressed in number of eggs/g of body weight. Wild females used for linear regression were three and four years old. Their lengths were included in a range $390-555 \mathrm{~mm}$. Reared females were three years old. Their lengths were included in a range $275-350 \mathrm{~mm}$.

\begin{tabular}{|c|c|c|c|c|}
\hline \multicolumn{5}{|c|}{$\begin{array}{l}\text { A) Linear regression between relative fecundity (F) } \\
\text { and weight of females (W). Wild females: } \\
\log (\mathrm{F})=5.072+0.386 \log (\mathrm{W}), r=0.193 \text { (NS). Reared } \\
\text { females: } \log (\mathrm{F})=5.356+0.076 \log \text { (W), } r=0.081 \\
\text { (NS) (winter } 1987-1988 \text { natural photoperiod). }\end{array}$} \\
\hline \multicolumn{2}{|r|}{$\begin{array}{l}\text { B) Relative fecundity for females of different origins. } \\
\text { Origins of females }\end{array}$} & $\begin{array}{c}\text { Age } \\
\text { (years) }\end{array}$ & Relative fecundity & Statistical analysis \\
\hline & Wild females & $3-4$ & (83) $45.07 \pm 0.89$ & $\begin{array}{l}1=* * \text { with all the other } \\
\text { groups }(2,3,4,5,6,7)\end{array}$ \\
\hline \multicolumn{5}{|c|}{ Reared females: } \\
\hline \multicolumn{5}{|c|}{ A) Natural photoperiod: } \\
\hline & 2 winter $1986 / 1987$ & 3 & (66) $26.84 \pm 0.86$ & $2-5=* *$ \\
\hline & 3 winter $1987 / 1988$ & 3 & (94) $32.29 \pm 0.77$ & $3-6=* *$ \\
\hline & 4 winter $1988 / 1989$ & 4 & (32) $32.79 \pm 1.70$ & $4-7=*$ \\
\hline \multicolumn{5}{|c|}{ B) Long days (17L-7 D): } \\
\hline & 5 winter $1986 / 1987$ & 3 & (19) $35.85 \pm 1.65$ & \\
\hline & 6 winter $1987 / 1988$ & 4 & (54) $39.32 \pm 1.20$ & \\
\hline & 7 winter $1988 / 1989$ & 4 & (47) $37.61 \pm 1.22$ & \\
\hline
\end{tabular}


females was included in the range $73-76 \%$ except for fish reared in natural photoperiod in winter $1987 / 1988$ $(64 \%)$.

\section{Weight of ova (tabl.3)}

Ova from reared fish kept in natural photoperiod had an average weight similar to wild fish, except in 1987/1988. The weight of ova from reared fish kept in long days was always lower than that of controls in natural photoperiod.

\section{Relative fecundity $(t a b l .4)$}

Relative fecundity did not change significantly with weight for both wild and reared females. Relative fecundity of wild females was always higher than that of reared females. For the latter, relative fecundity of fish kept under long days was always higher than that of controls under natural photoperiod.

\section{Patterns of overripening of eggs (fig. 4)}

In wild fish and in reared fish as well, ova maintained a maximum fertility for three or four days after ovulation at $5^{\circ} \mathrm{C}$. A week after ovulation, ova had completely lost their capacity to be fertilized. At 7.5 and $11^{\circ} \mathrm{C}$ the process of overripening was strongly accelerated.

\section{DISCUSSION}

The growth of whitefish fed with a dry food is slower than that of wild fish in Lake Geneva. However, the growth of wild whitefish in Lake Geneva is the highest in whitefish populations (Champigneulle et al., 1983). Moreover, the growth of reared whitefish in the present experiment was quite comparable to that of numerous whitefish populations (see Berg, 1970 for synthesis).

The ovulation of reared whitefish in tanks occurs spontaneously at the same spawning time, as for wild spawners from the lake. Whitefish kept under a normal thermoperiodic regime and subjected to long days (17 L-7 D) from mid summer show a delay in spawning. The mid period of ovulation occurs about two months after the control group kept under normal photoperiod. This result is in agreement with these for other salmonid fish that have been investigated so far (see Bromage and Duston, 1986 for synthesis). In autumn the ovaries develop more slowly in females under long days than in controls. This suggests that long days mainly act by a reduced efficiency of vitellogenesis, as has been reported in rainbow trout (Bourlier and Billard, 1984). Continuous exposure under long days until the spawning time leads to an occurence of the ovulations over three months while termination of the long day regime in December induces a synchronization of the ovulations over just a few weeks. According to Bromage et al. (1984) seasonally-changing cues, i.e. long days then short days, appear necessary to synchronize the ovulation in rainbow trout. But as far as whitefish is concerned, the short day cue may act only a few weeks prior to the onset of ovulations.

The survival rate of embryos is slightly lower for reared females than for wild ones. Howcver, the values for reared females are included in a normal range for wild coregonid eggs in hatchery (Wilkonska and Zuromska, 1982). In the present experiment, the survival rate of embryos has been measured at 120 degree-days. Subsequently, mortalities can still take place, but generally the majority of the mortalities takes place during the first third of the embryonic development, as in Vendace (Dabrowski et al., 1987). Furthermore, 800000 eggs have been produced by reared whitefish and incubated in zug glass. The larvae produced in this way have shown an ability to be reared comparable with wild ones (Rojas Beltran et al., 1990).

Relative fecundity and GSI are significantly higher in wild females than in reared ones. This may be related to the difference in growth between the two groups. Jensen (1981) has reported that relative fecundity tended to increase with growth rate in several whitefish populations. Moreover, Dabrowski and Champigneulle (1987) have noted that relative fecundity was correlated with GSI and the latter with body weight in whitefish from Lake Geneva. However, the relative fecundity of reared females is included in a normal range for whitefish populations (Machniak, 1975). The relative fecundity of reared females under long days is significantly higher than in controls under natural photoperiod. Conversely, the mean weight of ova changes in an opposite direction. In natural populations, coregonid species that spawned earlier had larger eggs and lower fecundity than the later spawners (Booke, 1970). It appears that the delay of spawning by artificial photoperiod regimes induces the same differences in reared coregonid spawners. In the last instance, genetic differences are excluded. Long daylengths and/or low temperatures for the end of vitellogenesis are probably responsible for these effects (smaller and more numerous eggs).

The process of overripening is complete in one week for the females reared at $5^{\circ} \mathrm{C}$. The same applies to wild fish. The severity of stress imposed on wild fish during gill net catches apparently does not modify the pattern of ageing of ova. At $7^{\circ} \mathrm{C}$ and above, the ova overripen faster. The same phenomenon has already been reported in rainbow trout and brown trout (Billard and Gillet, 1981). However, in trout, the acceleration of the ageing process is observed only above $10^{\circ} \mathrm{C}$. Spawning temperatures are generally very cold in whitefish populations (Machniak, 1975). This could be related to the low thermal requirements for the preservation of ova viability. 


\section{Acknowledgements}

I am greatly indebted to $\mathrm{A}$. Champigneulle for his assistance and for supplying the fingerling coregonid fishes adapted to artificial dry food. I thank Ph. Laurent for his technical assistance.

\section{REFERENCES}

Berg A., 1970. A comparative study of food and growth and competition between two species of coregonids introduced in lago Maggiorc, Italy. In: Biology of coregonid fishes. C. C. Lindsay, C. S. Woods ed. University of Manitoba press, Winnipeg, 311-346.

Billard'R., 1977. Utilisation d'un système Tris-Glycocolle pour tamponner le dilueur d'insémination pour la truite. Bull. Fr. Pêche Piscic., 284, 102-112.

Billard R., C. Gillet, 1981. Vieillissement des ovules et potentialisation par la température des effets des micropolluants du milieu aqucux sur les gamètes chez la truite. Cah. Lab. Montereau, 12, 35-42.

Booke H. E., 1970. Speciation paramcters in Coregonine fishes: I Egg-size. IJ Karyotype. In: Biology of coregonid fishes. C. C. Lindscy, C. S. Woods ed. University of Manitoba press. Winnipeg, 61-66.

Bourlier A., R. Billard, 1984. Delay of gametogenesis and spawning by constant illumination of rainbow trout (Salmo gairdneri) during the first reproductive cycle. Can. J. Zool., 62, 2183-2187.

Bromage N. R., J. A. K. Elliott, J. R. C. Springate, C. Whithead, 1984. The effects of constant photoperiods on the timing of spawning in the rainbow trout. Aquaculture, 48, 213-223.

Bromage N., J. Duston, 1986. The control of spawning in the rainbow trout (Salmo gairdneri Richardson) using photoperiod techniques. Inst. freshwater Res. Drottningholm, Rep., 63, 26-35.

Champigneulle A., 1988. A first experiment in mass-rearing of coregonid larvae in tanks with a dry food. Aquaculture, 74, 249-261.

Champigneulle A., D. Gerdeaux, C. Gillet, 1983. Les pêches de géniteurs de corégones dans le Léman français en 1982. Bull. Fr. Pêche Piscic., 290, 140-157.

Champigneulle A., R. Rojas Beltran, 1990. First attempts to optimize the mass rearing of whitefish (Coregonus lavaretus L.) larvae from Léman and Bourget lakes (France) in tanks and cages. Aquat. Living Resour., 3, 217-228.

Dabrowski K., A. Champigneulle, 1987. Chemical composition of whitefish (Coregonidae) from Lake Léman during spawning. Proc. V. Congr. Europ. Ichtyology. Stockholm, 335-338.

Dabrowski K., N. Luczynski, B. Czeczuga, S. Falkowski, 1987. Relationships among coregonid fish reproductive - effort, carotenoid content in eggs and survival of cmbryos. Arch. Hydrobiol. suppl., 79, 29-48.

Gcrdcaux D., 1985. Statistiques des pêches exceptionnelles de corégones dans les eaux françaises du Léman en 1985. Rapp. Inst. Limnol., Thonon $n^{\circ} 26-86,5 \mathrm{p}$.

Gillet C., P. Roubaud, 1986. Survie embryonnaire prćcoce de 9 espèces de poissons d'eau douce après un choc de pH appliqué pendant la fécondation ou au cours des premiers stades du développement embryonnairc. Reprod. Nutr. Dévelop., 26, 1319-1333.

Jensen A. L., 1981. Population regulation in lakes whitefish Coregonus clupeaformis (Mitchill). J. Fish. Biol., 19, 557573.

Kamler E,, H. Zuromska, T. Nissinen, 1988. Bioenergetical evaluation of environmental and physiological factors determining egg quality and growth in Coregonus albula (L.). Pol. Arch. Hydrobiol., 29, 71-121.

Luczynski M., 1984. Improvement in the efficiency of stocking lakes with larvae of Coregonus albula L., by delaying hatching. Aquaculture, 41, 99-111.

Luczinski M., 1986. A revicw on the biology, exploitation, rearing and management of coregonid fishes in Poland. Arch. Hydrobiol., 22, 115-140.

Machniak K., 1975. The effects of hydroelectric development on the biology of northern fishes (reproduction and population dynamics). I. Lake whitefish Coregonus clupeaformis (Mitchill). Fish. mar. serv. Tech. rep., n 527. Canada.

Rojas Beltran R., A. Champigneulle, N. Le Rouilly, 1990. Influence of egg origin and rearing conditions on the initial growth and survival of Coregonus lavaretus larvae fed on a dry diet. In: International symposium on biology and management of Coregonid fishes. Quebec (summary only).

Rösch R., 1988. Mass rearing of Coregonus lavaretus larvae on a dry dict. Finnish Fish Res., 9, 345-351.

Wilkonska H., H. Zuromska, 1982. Effect of environmental factors and egg quality on the mortality of spawn in Coregonus albula (L.) and Coregonus lavaretus (L.). Pol. Arch. Hydrobiol., 29-1, 123-157. 